DOE/OR/01-1395\&D1 Y/ER-248

\title{
Remedial Design Work Plan for Lower East Fork Poplar Creek Operable Unit, Oak Ridge, Tennessee
}

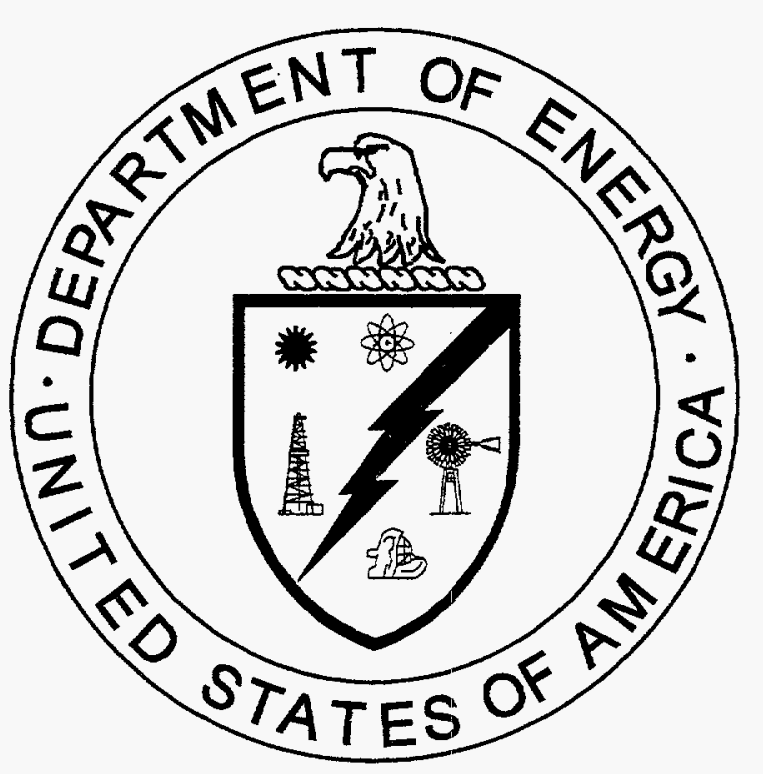

DEC 281955

OSTI 
This report has been reproduced directly from the best available copy.

Available to DOE and DOE contractors from the Office of Scientific and Technical Information, P.0. Box 62, Oak Ridge, TN 37831; prices available from 615-576-8401 (fax 615-576-2865).

Available to the public from the National Technical Information Service, U.S. Department of Commerce, 5285 Port Royal Rd., Springfield, VA 22161. 
DOE/OR/01-1395\&D1

Y/ER-248

Energy Systems Environmental Restoration Program

Y-12 Environmental Restoration Program

\author{
Remedial Design Work Plan \\ for Lower East Fork Poplar Creek \\ Operable Unit, Oak Ridge, Tennessee
}

Date Issued_October 1995

\author{
Prepared for \\ U.S. Department of Energy \\ Office of Environmental Management \\ under budget and reporting code EW 20 \\ Environmental Restoration Activities \\ OAK RIDGE Y-12 PLANT \\ Oak Ridge, Tennessee 37831-8169 \\ managed by \\ LOCKHEED MARTIN ENERGY SYSTEMS, INC. \\ for the \\ U.S. DEPARTMENT OF ENERGY \\ under contract DE-AC05-84OR21400
}





\section{PREFACE}

This Remedial Design Work Plan for Lower East Fork Poplar Creek (EFPC) (DOE/OR/01-1395\&D1) was prepared in accordance with requirements under the Comprehensive Environmental Response, Compensation, and Liability Act to present the plan for remedial design based on the selected remedy. This work was performed under Work Breakdown Structure 1.4.12.3.1.04 (Activity Data Sheet 9304, "Lower East Fork Poplar Creek"). Publication of this document meets a Federal Facility Agreement milestone of October 13, 1995. This document provides the Environmental Restoration Program with information about the selected remedy for Lower East Fork Poplar Creek, which involves excavating floodplain soil with mercury concentrations $>400$ parts per million and disposing of the soil at a landfill at the U.S. Department of Energy Oak Ridge Y-12 Plant. Information in this document summarizes the remedial design work plan for implementing the selected remedy summarized in the Record of Decision (DOE/OR/02-1370\&D2).

\section{DISCLAIMER}

This report was prepared as an account of work sponsored by an agency of the United States Government. Neither the United States Government nor any agency thereof, nor any of their employees, makes any warranty, express or implied, or assumes any legal liability or responsibility for the accuracy, completeness, or usefulness of any information, apparatus, product, or process disclosed, or represents that its use would not infringe privately owned rights. Reference herein to any specific commercial product, process, or service by trade name, trademark, manufacturer, or otherwise does not necessarily constitute or imply its endorsement, recommendation, or favoring by the United States Government or any agency thereof. The views and opinions of authors expressed herein do not necessarily state or reflect those of the United States Government or any agency thereof. 


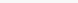




\section{DISCLAMMER}

Portions of this document may be illegible in electronic image products. Images are produced from the best available original document. 


\section{CONTENTS}

FIGURES $\ldots \ldots \ldots \ldots \ldots \ldots \ldots \ldots \ldots \ldots \ldots \ldots \ldots \ldots \ldots \ldots \ldots \ldots \ldots$ vii

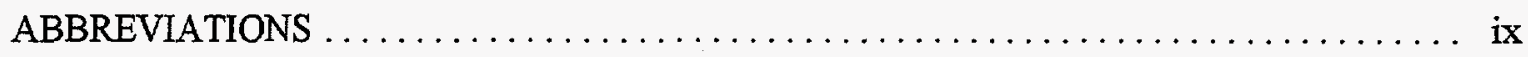

EXECUTIVE SUMMARY $\ldots \ldots \ldots \ldots \ldots \ldots \ldots \ldots \ldots \ldots \ldots \ldots \ldots \ldots \ldots \ldots$

1. INTRODUCTION $\ldots \ldots \ldots \ldots \ldots \ldots \ldots \ldots \ldots \ldots \ldots \ldots \ldots \ldots \ldots \ldots \ldots \ldots \ldots$

1.1 PURPOSE AND SCOPE OF THE REMEDIAL DESIGN WORK PLAN $\ldots \ldots \ldots \ldots$.

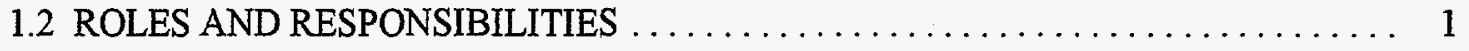

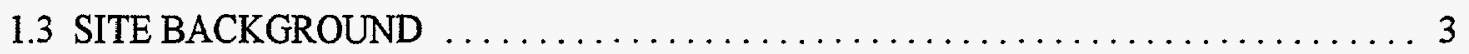

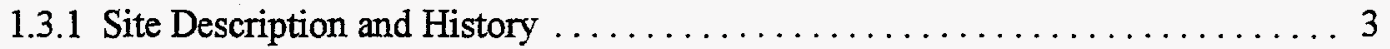

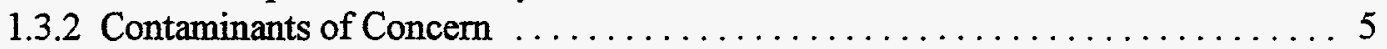

2. TECHNICAL APPROACH TO REMEDIAL DESIGN $\ldots \ldots \ldots \ldots \ldots \ldots \ldots \ldots \ldots$

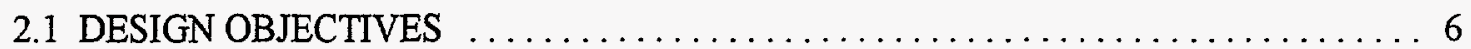

2.2 REMEDIAL DESIGN APPROACH $\ldots \ldots \ldots \ldots \ldots \ldots \ldots \ldots \ldots \ldots \ldots \ldots \ldots \ldots \ldots \ldots$

2.3 REGULATORY CONSIDERATIONS DURING REMEDIAL DESIGN $\ldots \ldots \ldots \ldots 7$

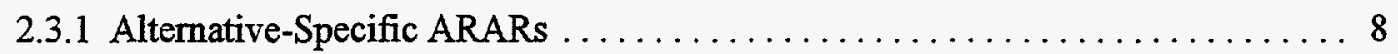

2.3.2 Permitting Considerations/Exceptions $\ldots \ldots \ldots \ldots \ldots \ldots \ldots \ldots \ldots \ldots$

2.4 DESIGN CRITERIA AND ASSUMPTIONS $\ldots \ldots \ldots \ldots \ldots \ldots \ldots \ldots \ldots \ldots$

3. REMEDIAL DESIGN PLANNING $\ldots \ldots \ldots \ldots \ldots \ldots \ldots \ldots \ldots \ldots \ldots \ldots \ldots$

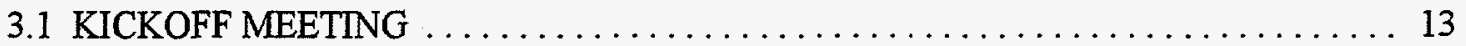

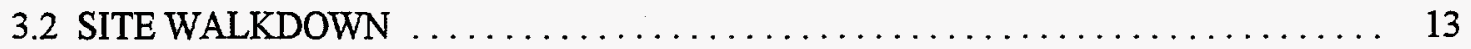

3.3 ACQUISITION AND EVALUATION OF EXISTING DATA $\ldots \ldots \ldots \ldots \ldots \ldots \ldots$

3.4 PREPARATION OF SECONDARY RD SUPPORT PLANS $\ldots \ldots \ldots \ldots \ldots \ldots \ldots \ldots$

3.4.1 Engineering Quality Assurance Plan $\ldots \ldots \ldots \ldots \ldots \ldots \ldots \ldots \ldots$

4. REMEDIAL DESIGN $\ldots \ldots \ldots \ldots \ldots \ldots \ldots \ldots \ldots \ldots \ldots \ldots \ldots \ldots \ldots \ldots \ldots \ldots$

4.1 PRELIMINARY AND INTERMEDIATE DESIGN (TITLE I AND

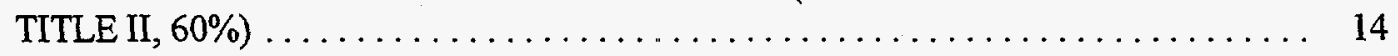

4.2 PREFINAL/FINAL DESIGN (TITLE II, 90\%, 100\%, AND CFC) . . . . . . . 15

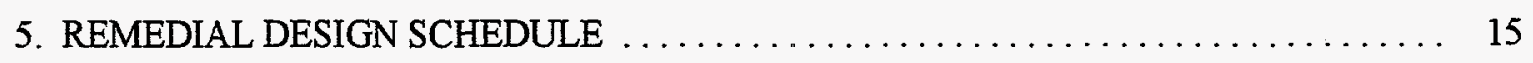

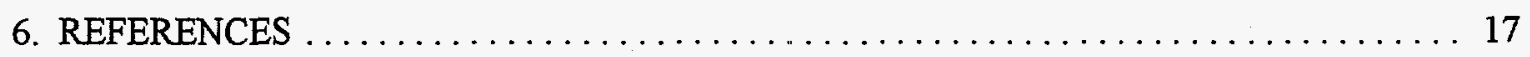

APPENDIX A: List of ARARs 



\section{FIGURES}

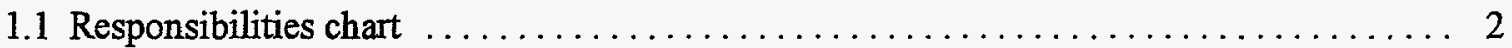

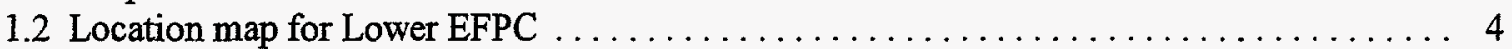

2.1 National Oceanic and Atmospheric Administration Site $\ldots \ldots \ldots \ldots \ldots \ldots \ldots \ldots$

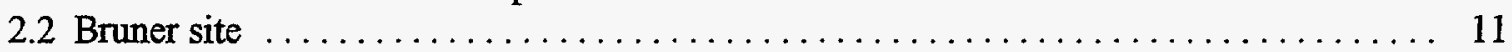

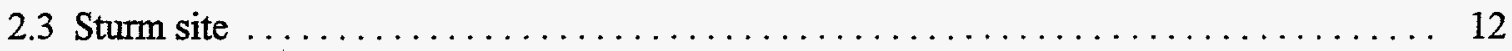

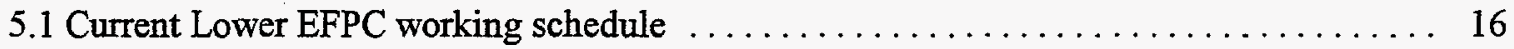





\section{ABBREVIATIONS}

ARARs

CERCLA

CFC

CFR

DOE

DOE-HQ

DOE-ORO

EFPC

EPA

FFA

FWENC

Energy Systems

NOAA

ORR

OU

PCB

ppm

RA

RCRA

$\mathrm{RD}$

RDWP

ROD

TDEC applicable or relevant and appropriate requirements

Comprehensive Environmental Response, Compensation, and Liability

Act

certified for construction

Code of Federal Regulations

U.S. Department of Energy

U.S. Department of Energy-Headquarters

U.S. Department of Energy-Oak Ridge Operations

East Fork Poplar Creek

U.S. Environmental Protection Agency

Federal Facility Agreement

Foster Wheeler Environmental Corporation

Lockheed Martin Energy Systems, Inc.

National Oceanic and Atmospheric Administration

Oak Ridge Reservation

Operable Unit

polychlorinated biphenyl

parts per million

remedial action

Resource Conservation and Recovery Act

remedial design

remedial design work plan

Record of Decision

Tennessee Department of Environment and Conservation 


\section{EXECUTIVE SUMMARY}

The Remedial Design Work Plan (RDWP) for Lower East Fork Poplar Creek (EFPC) Operable Unit (OU) in Oak Ridge, Tennessee, has been prepared in response to direction from the U.S. Department of Energy (DOE) under Contract No. DE-AC05-84OR21400. This remedial action fits into the overall Oak Ridge Reservation (ORR) cleanup strategy by addressing contaminated floodplain soil. The objective of this remedial action is to minimize the risk to human health and the environment from contaminated soil in the Lower EFPC floodplain pursuant to the Comprehensive Environmental Response, Compensation, and Liability Act (CERCLA) and the Federal Facility Agreement (FFA) (1992).

The ORR is located in Oak Ridge, Tennessee, approximately $32 \mathrm{~km}$ (20 miles) west of Knoxville, Tennessee. The Oak Ridge Y-12 Plant is located on 324 ha ( 800 acres) in Bear Creek Valley, $3.2 \mathrm{~km}$ (2 miles) south of downtown Oak Ridge. The Lower EFPC OU site includes the soil and sediment in the 100-year floodplain along Lower EFPC and the Sewer Line Beltway. The Lower EFPC OU begins at the outfall of Lake Reality and ends at its confluence with Poplar Creek $23.3 \mathrm{~km}$ (14.5 miles) downstream. In addition, floodplain soils from Lower EFPC served as backfill material for construction of the Sewer Line Beltway through the city of Oak Ridge, and these soils are included in the OU site. The OU includes portions of ORR and commercial, residential, agricultural, and miscellaneous areas within the city of Oak Ridge.

In accordance with the FFA, a remedial investigation (RI) (DOE 1994a) and a feasibility study (DOE 1994b) were conducted to assess contamination of the Lower EFPC and propose remediation alternatives. The remedial investigation determined that the principal contaminant is mercury, which originated from releases during Y-12 Plant operations, primarily between 1953 and 1963. The recommended alternative by the feasibility study was to excavate and dispose of floodplain soils contaminated with mercury above the remedial goal option.

Following the remedial investigation/feasibility study, and also in accordance with the FFA, a proposed plan (DOE 1995a) was prepared to more fully describe the proposed remedy. Thereafter, a public hearing was held to review the proposed plan. Comments were incorporated. The revised selected remedy, per the Record of Decision (ROD) (DOE 1995b) is to excavate and dispose of floodplain soils contaminated above the remediation goal of $400 \mathrm{ppm}$ mercury. The approved ROD with this goal will be the basis for remedial design (RD).

RD will encompass design for the remediation sites. Preparatory activities, including establishment of a design basis, will precede the $R D$. Design reviews, which include technical and constructability reviews, will be performed at various stages throughout the project. All design efforts are scheduled to be completed to support the remediation schedule. 


\section{INTRODUCTION}

The remedial design (RD) activities will be performed to implement the Record of Decision (ROD) according to the established phases of the Comprehensive Environmental Response, Compensation, and Liability Act (CERCLA).

The $\mathrm{RD}$ work plan (RDWP) is comprised of six chapters. This introductory chapter describes the purpose and scope of the RDWP; the selected remedy as identified by the ROD; the roles and responsibilities of the $\mathrm{RD}$ team members; and the site background information, including site history, contaminants of concern, and site characteristics. Chapter 2 contains the design objectives, RD approach, regulatory considerations during $R D$, and the design criteria with assumptions. Chapter 3 presents the RD planning process to prepare this RDWP, as well as secondary RD support plans. Chapter 4 describes the scope of the RD activities in more detail and identifies what will be included in the design package. Chapter 5 presents the schedule for performance of the RD activities, identifying key $\mathrm{RD}$ milestones. Specific documents used in the preparation of this document are referenced in Chapter 6.

\subsection{PURPOSE AND SCOPE OF THE REMEDIAL DESIGN WORK PLAN}

The purpose of this RDWP is to define the scope of activities necessary to develop an adequate database for design and to perform the design and engineering activities for the remediation of the Lower East Fork Poplar Creek (EFPC) Operable Unit (OU) project in accordance with the selected remedy defined in the ROD. In addition, applicable or relevant and appropriate requirements (ARARs) will be addressed. This document will also provide a schedule for completing the project.

In general, the selected remedy as defined in the ROD is for floodplain soils with mercury concentrations greater than the remediation goal of $400 \mathrm{ppm}$ to be excavated and disposed of in a permitted landfill at the Oak Ridge Y-12 Plant. A small area of wetlands will be remediated and restored. Clean borrow soil will be needed to fill the excavated areas. Implementation of this alternative may involve building additional roads, and will involve removing vegetation and soils, grading excavated areas, and controlling surface runoff.

\subsection{ROLES AND RESPONSIBILITIES}

The implementation of the selected remedy consists of the $R D$ stage and the remedial action (RA) stage. This project will be accomplished by the U.S. Department of Energy (DOE); Lockheed Martin Energy Systems, Inc., (Energy Systems) as the facility management contractor; the technical support contractor; the RD contractor; and the RA construction manager. (See Fig. 1.1.) The project will be managed in accordance with the requirements established by the Environmental Restoration Program using an integrated team approach.

The RD effort will include Titles I and II engineering and associated plans. The RA will involve procurement of materials, Title III engineering services, construction for remediation of the Lower EFPC floodplain soils, construction of associated support facilities, any utility and service tie-ins, and land restoration. 


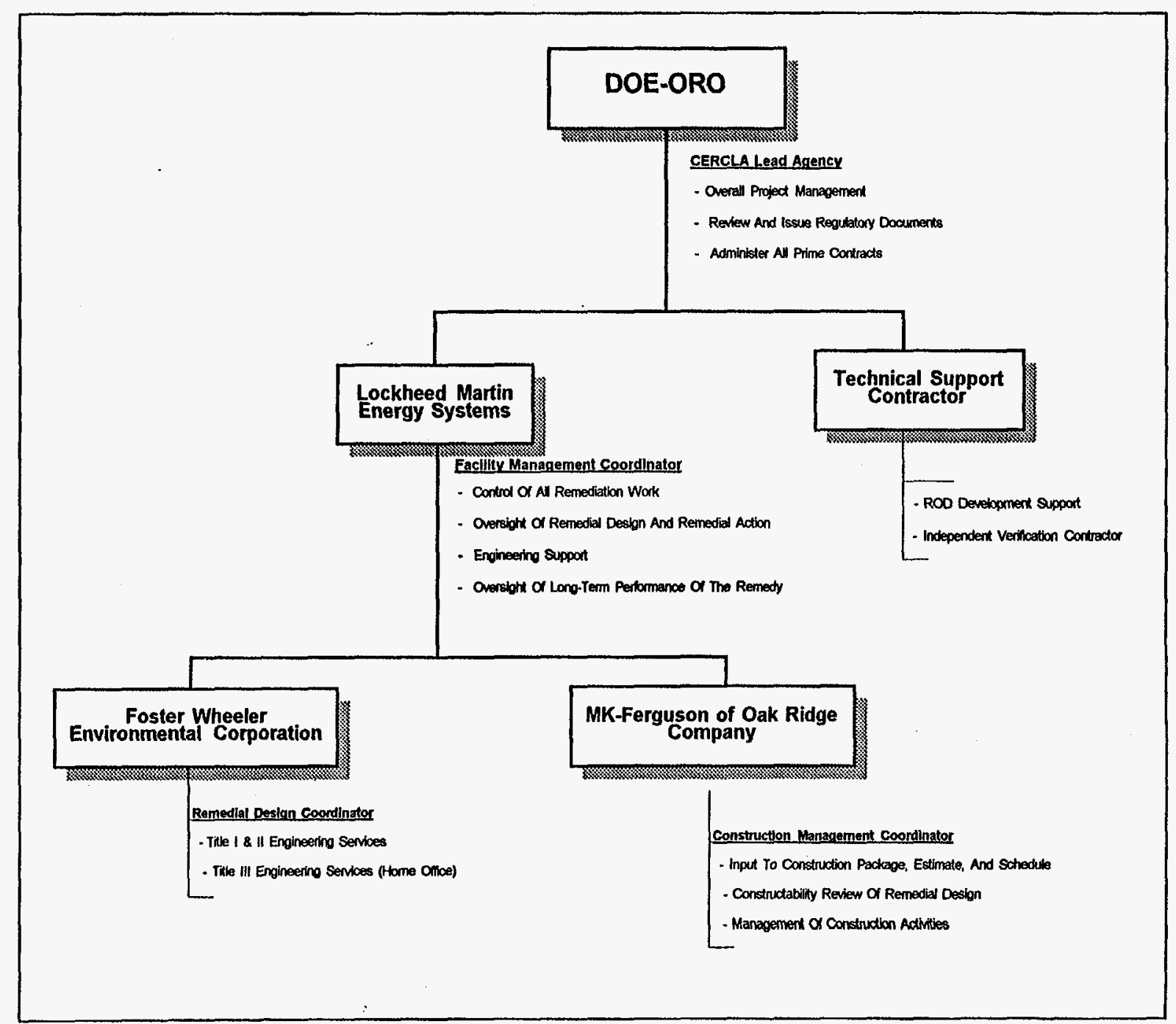

Fig. 1.1. Responsibilities chart. 
The organizational structure for this project is described as follows:

DOE-Headquarters (DOE-HQ), having the responsibility of environmental restoration, delegates the direct management of environmental restoration activities on the Oak Ridge Reservation (ORR) to DOE-Oak Ridge Operations (DOE-ORO). DOE-ORO is also designated as the CERCLA lead agency. DOE-ORO has delegated the overall project management to the facility management contractor through a task order contract. DOE-ORO will participate in document/design reviews and approve all Federal Facility Agreement (FFA) documents.

The facility management contractor for DOE-ORO is Energy Systems. All work, including oversight responsibility for implementing the remedy as outlined in the ROD, is performed under the Facility Manager's control. Energy Systems will also provide Title III field support.

The technical support contractor, currently Jacobs Engineering Group, Inc., provides technical support to DOE-ORO. For this project, the technical support contractor will provide all ROD development support and will also serve as the independent verification contractor.

Foster Wheeler Environmental Corporation (FWENC) is the Environmental Restoration and Waste Management design contractor for the design of RA projects. As the RD contractor, FWENC will provide Title I, II, and III engineering services. Their primary function will be to prepare Title I (preliminary) and Title II (intermediate and final) design documents that provide a set of plans and specifications for the proposed remediation consistent with the requirements of the ROD. Title III engineering services include home office support.

The construction management contractor is MK-Ferguson of Oak Ridge Company. Their primary responsibility is the management of the construction outlined in the $R D$. This will include performing construction management services for the construction involved with the RA and performing a review function during the $\mathrm{RD}$ phase, which includes input to portions of the construction package, construction cost estimate, and construction schedule.

\subsection{SITE BACKGROUND}

\subsubsection{Site Description and History}

The ORR is made up of three major DOE installations located in Tennessee, constructed as research, development, and process facilities in support of the wartime Manhattan Project. These installations include the Y-12 Plant, Oak Ridge National Laboratory, and the Oak Ridge K-25 Site, formerly the Oak Ridge Gaseous Diffusion Plant. The ORR also includes areas outside the installations, land used by Oak Ridge Associated Universities, the Oak Ridge Institute of Science and Education, and waterways that have been contaminated by releases from DOE installations.

The Lower EFPC OU site includes the soil in the 100-year floodplain along Lower EFPC and the Sewer Line Beltway. (See Fig. 1.2.) More than 20 tributaries and treated effluent from the Oak Ridge Sewage Treatment Plant flow into the creek. EFPC begins within the Y-12 Plant as the Upper EFPC, which is a separate Characterization Area. Upper EFPC terminates at Lake Reality, a retention pond at the east end of the Y-12 Plant. The Lower EFPC OU begins at the outfall of Lake Reality and ends at its confluence with Poplar Creek $23.3 \mathrm{~km}$ (14.5 miles) downstream. In addition, floodplain soils from Lower EFPC served as backfill material for construction of the Sewer Line Beltway 


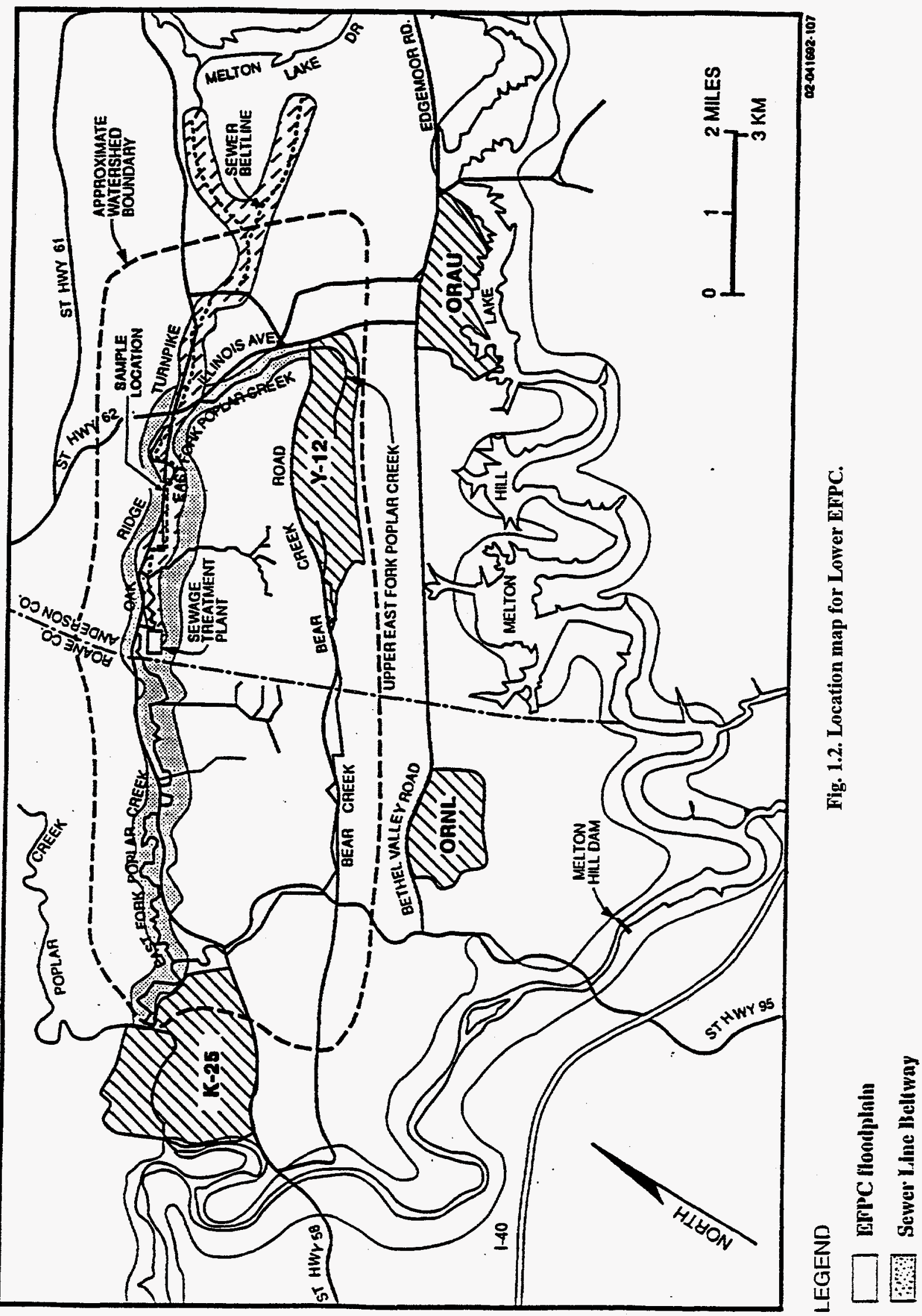


through the city of Oak Ridge, and these soils are considered part of the site. Since the CERCLA risk assessment process and the remedial investigation report confirmed Sewer Line Beltway soils present no significant risk, the beltway is not included in the remediation. The site includes portions of ORR and commercial, residential, agricultural, and miscellaneous areas within the city of Oak Ridge.

The Y-12 Plant was built in the 1940s as part of the Manhattan Project attempt to separate uranium isotopes using electromagnetic fields. After World War II, the plant's role shifted to developmental engineering and manufacturing and included the following activities:

- production of nuclear weapon components and subassemblies,

- development and fabrication of test hardware for weapon design laboratories,

- fabrication support for other DOE sites, and

- related support of other federal agencies.

Beginning in 1953, operation of the lithium isotope separation processes at the Y-12 Plant resulted in the release of 108,000 to $212,000 \mathrm{~kg}(239,000$ to $470,000 \mathrm{lb})$ of mercury into Lower EFPC. Although mercury loss from the Y-12 Plant operation stopped in 1963, mercury continues to be released into Lower EFPC from secondary contaminated sources (e.g., building drain systems, sewers, and connecting lines) at the plant. The current release averages approximately $20 \mathrm{~g} /$ day $(0.7 \mathrm{oz} . / \mathrm{day})$, down from $100 \mathrm{~g} /$ day $(3.5 \mathrm{oz} . /$ day) in 1985 . Portions of the Y-12 Plant sewers were relined in 1986-1987 to reduce mercury losses. Efforts continue to further reduce mercury losses (e.g., decontamination and decommissioning, reduction of mercury in plant effluents, and remediation of mercury-use areas) with a goal of meeting the requirements of the National Pollutant Discharge Elimination System permit.

The state of Tennessee posted advisory signs in 1983 warning the public that Lower EFPC was contaminated. In 1989, the ORR was placed on the National Priorities List and designated as a CERCLA site requiring investigation. In accordance with CERCLA and as agreed to in the FFA (DOE 1992) by DOE, the U.S. Environmental Protection Agency (EPA), and the Tennessee Department of Environment and Conservation (TDEC), a remedial investigation (DOE 1994a) and a feasibility study (DOE 1994b) were conducted, and a Proposed Plan (DOE 1995a) was developed.

\subsubsection{Contaminants of Concern}

The results of the baseline human health and ecological risk assessments confirmed mercury as the primary contaminant of concern in Lower EFPC. For the heavy metals, mercury was by far the most significant risk contributor, accounting for greater than $85 \%$ of the total noncarcinogenic risk. For radionuclides, total uranium accounted for $98 \%$ of the total activity. However, risk associated with radionuclides fell within the EPA acceptable target range in all cases. The organic compound groups of polycyclic aromatic hydrocarbons and polychlorinated biphenyls (PCBs) did not substantially contribute to the estimated risks to human health. 


\section{TECHNICAL APPROACH TO REMEDIAL DESIGN}

\subsection{DESIGN OBJECTIVES}

The objective of the RD is to develop the necessary design documents to be used as the basis for excavation and disposal of the identified floodplain soils contaminated above the risk-based remediation goal of $400 \mathrm{ppm}$ mercury at Lower EFPC OU.

Performance, equipment and/or construction specifications will be prepared, along with the design drawings for the excavation work and all other appurtenant equipment and structures. These documents will be included in a bid package that will enable the construction manager to manage the site remediation and restoration. Other project work, such as media sampling and analysis and management of environmental and regulatory issues, will be addressed concurrently or as necessary to support design and engineering activities.

\subsection{REMEDIAL DESIGN APPROACH}

EPA encourages phasing and fast-tracking wherever possible to expedite the project schedule. Through phasing and fast-tracking, design requirements are consolidated into a schedule that will achieve the selected RA within the time frame agreed upon between the responsible party and the state. Fast-tracking will be accomplished for this project through the use of on-board and concurrent reviews of the design documents and through streamlining the preparation of specific design packages.

The $\mathrm{RD}$ will be accomplished in the following manner to allow sufficient time for all design efforts to be completed to support the remediation schedule defined in the FFA:

- The $\mathrm{RD}$ will address the design for the remediation sites. Design drawings and specifications will identify areas to be excavated, extent of excavation, plans for site restoration, specific remediation construction requirements, etc. The remediation construction will be integrated with Industrial Landfill V at the Y-12 Plant, which is currently under construction and expected to be available by the beginning of the soil excavation phase.

- The fast-track design approach, as endorsed by EPA, will be implemented by the use of on-board reviews to reduce the duration of review steps required to complete each phased element and to optimize the overall schedule. For an on-board review, design drawings and documents will be distributed in advance of a meeting to discuss and resolve comments. There will be no formal response to comments following the meeting. The intermediate (60\%) design package will be distributed to DOE, EPA, and TDEC for informal review and comment, concurrent with distribution to the construction management and facility management contractors for the on-board review.

- The prefinal (90\%) design package will be provided to EPA and TDEC, concurrent with its issuance as the "D0" submittal to DOE, the construction management contractor, and the facility management contractor for the on-board review. 
- The final $(100 \%)$ design package will be issued to EPA and TDEC as the "D1" submittal for review and approval. There is no D2 submittal anticipated, based on the early involvement of EPA and TDEC at the $60 \%$ and $90 \%$ design stages.

The performance of the $\mathrm{RD}$ work assignment will entail the engineering of system components and preparation of technical specifications and drawings. A brief description of each design phase is presented in Chapters 3 and 4.

\subsection{REGULATORY CONSIDERATIONS DURING REMEDIAL DESIGN}

The selected remedy meets all ARARs, which are listed in Appendix A. Chemical-specific ARARs include only maximum contaminant levels for drinking water and are not directly associated with the selected remedy for Lower EFPC. Location-specific ARARs include requirements to avoid or minimize adverse impacts to wetlands. When such impacts cannot be avoided, mitigation and restoration or compensation is required. The selected remedy involves disturbance of approximately 1.5 acres of wetlands at the Bruner Center and National Oceanic and Atmospheric Administration (NOAA) locations. These wetlands primarily serve as wildlife habitat but also have low floodflow attenuation and sediment retention functions. The disturbed area will be remediated and restored. A wetlands and floodplain assessment was performed, per 10 Code of Federal Regulations (CFR) 1022, as part of the remedial investigation, after the wetlands were delineated by the U. S. Corps of Engineers (DOE 1994a). A Wetlands Mitigation Plan will be prepared before initiation of activities in the wetlands.

Since the RA will occur in a floodplain, actions must minimize any unavoidable, adverse impacts. A notice of floodplain and wetlands involvement was published for the actions in the Lower EFPC wetlands and floodplain on October 4, 1993 (58 Federal Register 51623-4). A floodplain assessment was performed (DOE 1994a) as mentioned above. A statement of findings was subsequently published in compliance with review requirements for proposed action. The statement of findings is provided in the feasibility study (DOE 1994b) and will be published in the Federal Register before the action is initiated. It specifies several measures DOE will take to minimize potential harm within the affected floodplain. Soil erosion and sediment control requirements will be specified, excavation will be scheduled during dry periods, obstruction to the stream will be avoided, approximate original contours will be restored, haul roads will not follow the shoreline, disturbance will be minimized in every possible way, and standard construction equipment will be used. Other location-specific ARARs are related to cultural resources and will be invoked if discoveries of cultural resources should be made during remedial activities. Action-specific ARARs for RA at Lower EFPC include requirements for surface water controls using site planning and best management practices to minimize adverse effects from erosion and storm water discharges into the creek, which could result from activities such as clearing, grading, and excavation. Precautions will be taken to prevent fugitive dust that may result from handling and transport of soils and sediments from becoming airborne.

A best management practices plan will be prepared and followed to address minimizing the potential to release hazardous substances into surface waters ( 40 CFR 125.104), to control storm water discharges (40 CFR 122, TDEC 1200-4-10-.05), and for nonpoint source controls (TDEC 1200-4-3-.06). These practices will be identified by complying with the substantive requirements of the storm water permitting process (40 CFR 122, TDEC 1200-4-10-.05). Consultation with TDEC will be necessary to ensure compliance with the substantive requirements of the aquatic 
resource alteration permit process (TDEC 1200-4-7) for activities such as minor road crossings, land stabilization, revegetation, etc.

Waste generators are required to determine whether the waste is hazardous (40 CFR 262.11, TDEC 1200-1-11-.06). Previous sampling has indicated that the soils in the Lower EFPC floodplain are not hazardous as defined by the Resource Conservation and Recovery Act (RCRA) (Characterization Report for Lower East Fork Poplar Creek Floodplain Soils, DOE/OR/02-1387\&D1). However, should any secondary wastes generated as part of the project be characterized as hazardous, appropriate requirements for the handling and disposal of these wastes will be invoked. Waste characterized as hazardous cannot be disposed in Y-12 Plant landfills. Non-RCRA characteristic excavated soils will be disposed of in an industrial waste landfill at the Y-12 Plant on the ORR as a special waste (TDEC 1200-1-7-.01 et seq.).

\subsubsection{Alternative-Specific ARARs}

During the $\mathrm{RD}, \mathrm{FWENC}$ will review the ARARs identified in Appendix $\mathrm{A}$ to ensure that appropriate guidance is addressed in the design. Federal, state, and local regulations, codes, and standards, such as building codes, fire codes, traffic regulations, etc., will be taken into consideration during preparation of the design documents.

\subsubsection{Permitting Considerations/Exceptions}

A variety of permitting requirements must be taken into consideration during the design process. On-site actions at CERCLA sites must comply only with the substantive requirements of ARARs, which include cleanup standards and other environmental protection criteria. Administrative requirements of ARARs, such as reporting, record keeping, or permitting, do not need to be complied with at sites. CERCLA Sect. 121(e)(1) specifically mandates that no federal, state, or local permits are required for response actions that occur entirely on site. This permit waiver applies to any site addressed under CERCLA removal or remedial authority. For the EFPC project, all ARARs and associated permits will be reviewed and the substantive requirements met. A special waste permit is being obtained to allow disposal of contaminated soils and similarly contaminated media at the disposal landfill.

\subsection{DESIGN CRITERIA AND ASSUMPTIONS}

The following assumptions have been used in the development of this RD work scope. The assumptions are identified here to assist the reviewer in understanding the boundaries within which the RD task activities, scheduling, and budgeting of the project are conducted.

- The RD will be developed based on the ROD approved by EPA on August 18, 1995, which makes certain assumptions based upon current guidance and policies.

- The remedy selected in the ROD will be designed based on Alternative 3 of the feasibility study (DOE 1994b).

- The remedy selected in the ROD excavates identified floodplain soils contaminated above the risk-based remediation goal of $400 \mathrm{ppm}$ mercury. It is estimated that the amount of excavated material requiring disposal is approximately $25,000 \mathrm{yd}^{3}$. 
- The areas to be excavated include two areas at the NOAA site (Parcels 571 and 461) and two areas at the Bruner's Center site (Parcels 564 and 563). The mercury contamination above 400 $\mathrm{ppm}$ in the areas at the NOAA site extends approximately 16 in. deep. The mercury contamination above $400 \mathrm{ppm}$ in the areas to be excavated at the Bruner's Center site is principally at depths of 16 in. with a few locations extending to 32 in. deep. (See Figs. 2.1, 2.2, and 2.3.)

- Contaminated soil will be disposed of in a state-approved, permitted, lined landfill at the Y-12 Plant. The landfill will have leachate collection capabilities and, if necessary, any leachate collected will be pretreated before discharge. Design and construction of a new landfill area are ongoing. It is assumed that the line item funding for the landfill will be continued to support the Lower EFPC project. Soils which are disposed in the landfill must meet special waste requirements.

- Staging areas will be provided for equipment storage, decontamination areas, dewatering/drying areas, mobile treatment facility, and other appurtenant structures, as required.

- Decontamination water, rainwater inflow, and groundwater infiltration into open excavation areas will be collected for sampling and/or treatment as required and dispositioned in an acceptable manner. Cleaning water will be recycled when possible.

- The remedy selected includes remediating and restoring approximately 1.5 acres of wetlands. A Wetlands Mitigation Plan will be developed and implemented.

- Independent verification will be performed to ensure that all mercury concentrations above $400 \mathrm{ppm}$ have been removed in the excavated areas. Results of analyzed samples below $400 \mathrm{ppm}$ will verify that excavation is complete.

- Excavated areas will be backfilled with clean borrow soil. Species of vegetation similar to those removed during excavation will be planted at all excavated areas.

- Lower EFPC sediment, surface water, soil, and associated organisms are currently being monitored under the Biological Monitoring and Abatement Program. This monitoring will continue throughout the construction effort and following construction for a period up to five years. The details of this monitoring approach will be outlined as part of $R D$.

- Capital, operational, and maintenance costs of the RA will be based on readily available vendor information and regional market data.

\section{REMEDIAL DESIGN PLANNING}

The following project planning activities and efforts are to be initiated before the design process:

- kickoff meeting,

- site walkdown,

- acquisition and evaluation of existing data, and

- preparation of secondary RD support plans. 


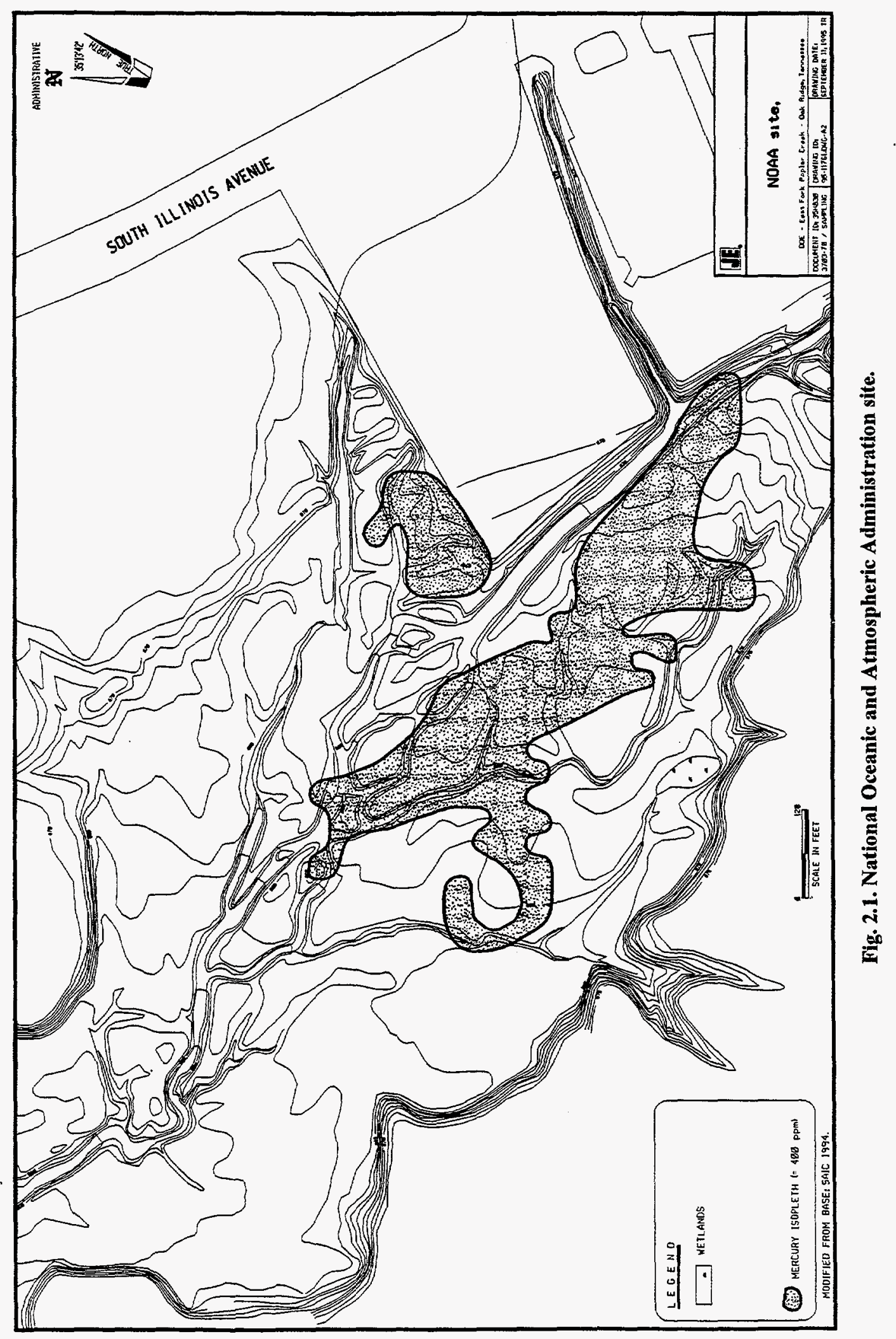




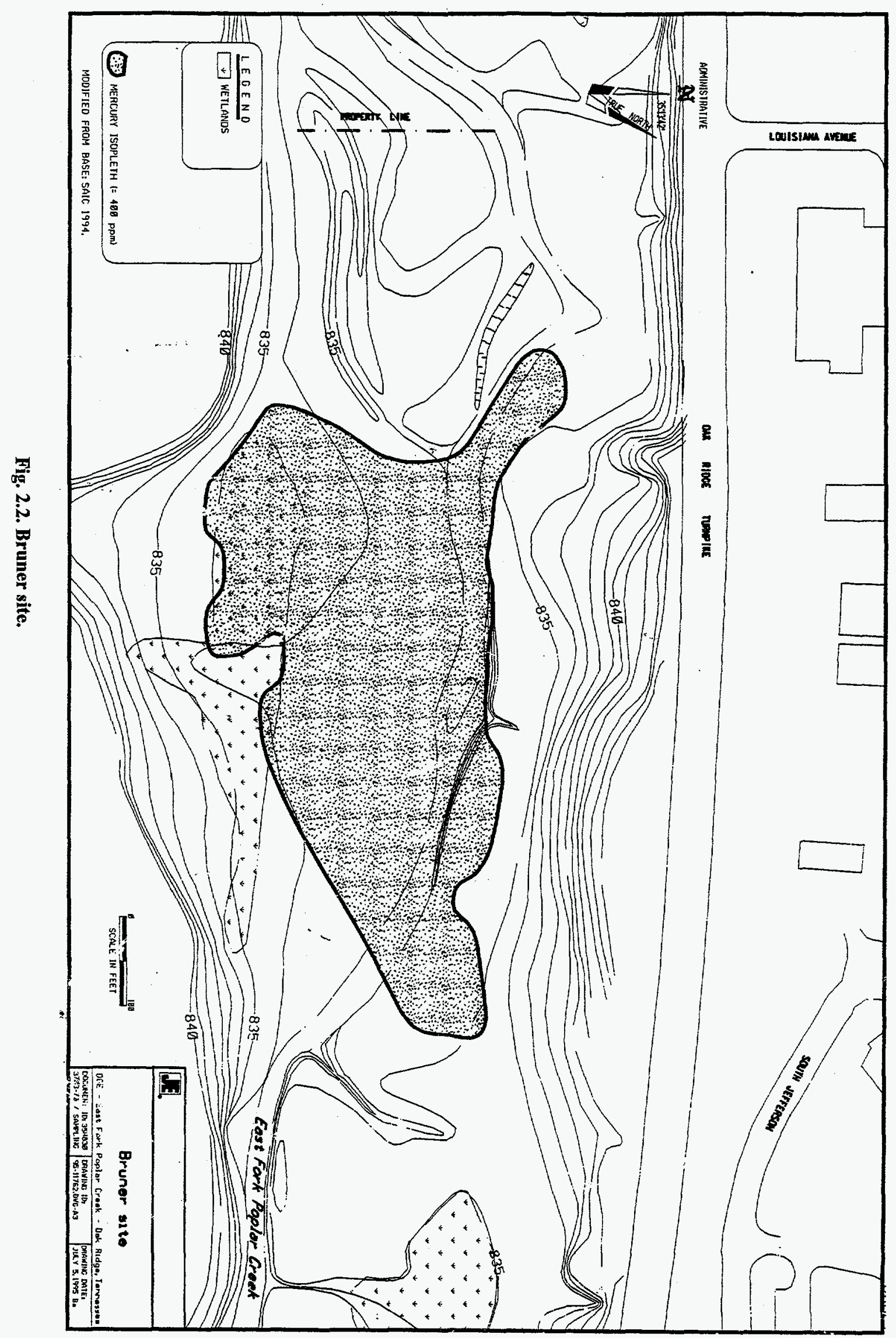




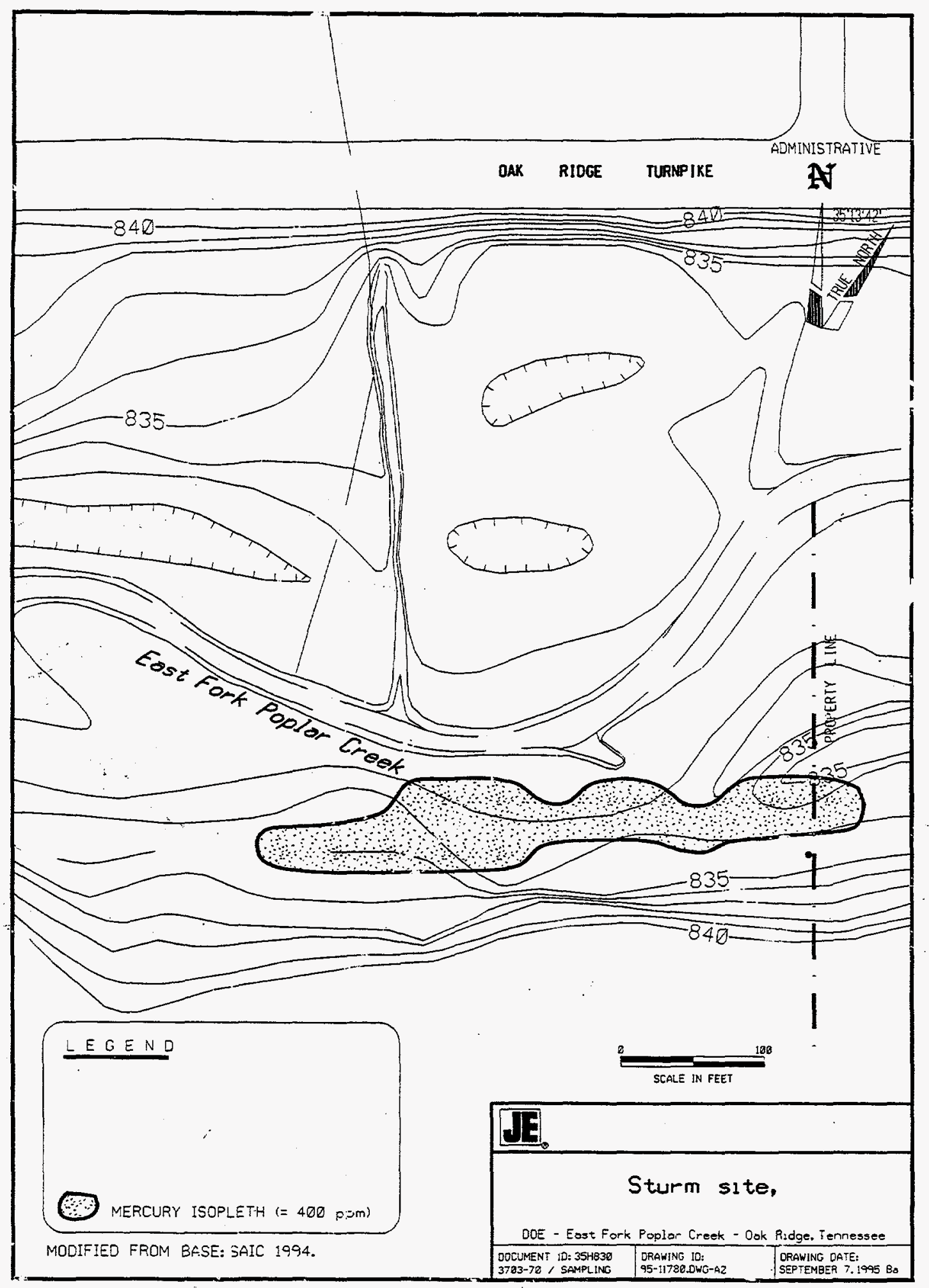

Fig. 2.3. Sturm site. 


\subsection{KICKOFF MEETING}

A kickoff meeting will be held prior to the start of the $\mathrm{RD}$ effort. The meeting will be attended by members of the RD contractor team and DOE, the facility management contractor, and the construction manager. In this meeting, the scope of work and technical approach for the design will be discussed, as well as plans for the other project planning activities.

In addition, items included in the statement of work, along with their impacts on the overall project budget and schedule will be addressed. The practicability and usefulness of performing any additional tests during the $\mathrm{RD}$ to supplement the data gathered during the remedial investigation and feasibility study will also be addressed.

\subsection{SITE WALKDOWN}

A site reconnaissance will be conducted prior to $R D$ to familiarize the $R D$ contractor team with details of the site layout and surroundings. Physical features of the general site terrain, along with notable site conditions, such as nearby wetland areas that may impact the environmental/regulatory aspects of the project, will be observed. The responsibility for obtaining access agreements to private and public properties will be with DOE-ORO.

\subsection{ACQUISITION AND EVALUATION OF EXISTING DATA}

The $\mathrm{RD}$ contractor team will gather applicable documentation regarding the project and previous site activities and review them to establish a design database. Existing applicable reports will be evaluated to verify that engineering parameters, such as geotechnical information, have been established. Review and evaluation of existing documentation and reports will be conducted prior to initiating efforts to obtain new information, thus eliminating the possibility of duplicating previous efforts. If data gaps are identified, an engineering data collection plan will be prepared to perform the additional field activities to complete the $\mathrm{RD}$ database.

\subsection{PREPARATION OF SECONDARY RD SUPPORT PLANS}

The Engineering Quality Assurance Plan (Ebasco 1992), which is described in the following section, is the only applicable support plan required for the initialization of the $\mathrm{RD}$ work effort.

\subsubsection{Engineering Quality Assurance Plan}

The RD contractor's quality assurance procedures, in accordance with the DOE-approved quality assurance plan developed for the Environmental Restoration/Waste Management Program, will be used in conjunction with applicable DOE orders and applicable facility management procedures to ensure that all design activities are performed in a controlled and systematic manner and in compliance with this RDWP. (See Ebasco 1992). 


\section{REMEDIAL DESIGN}

The completed $\mathrm{RD}$ will include, as a minimum, the following:

- design calculations and analyses,

- drawings,

- technical specifications,

- construction schedule, and

- $\quad$ certified for construction (CFC) package.

Design calculations and analyses will be summarized in a format appropriate for review and record purposes. This design will be transferred to drawings and/or technical specifications. Additionally, working drawings and sketches may be developed for the purpose of material quantification to enable the $\mathrm{RD}$ contractor to prepare the construction cost estimate and construction schedule. A CFC package will then be developed, which will consist of the drawings, technical specifications, and contract requirements and include the following plans and requirements as a minimum:

- confirmatory sampling plan,

- site health and safety requirements,

- construction quality assurance requirements,

- environmental monitoring plan,

- best management practices plan,

- wetlands mitigation plan,

- aquatic resource alteration permit,

- transportation plan

- waste management plan, and

- contingency plan.

\subsection{PRELIMINARY AND INTERMEDIATE DESIGN (TITLE I AND TITLE II, 60\%)}

A design concept concurrence review of the preliminary (30\%) design package will be conducted. An intermediate design package will be required at approximately $60 \%$ design complete. An advance copy of the $60 \%$ design package will be provided to the construction management contractor and the facility management contractor for review and comments. Additionally, the $60 \%$ design package will also be provided to DOE, EPA, and TDEC for informal review and comment. An on-board review will be conducted. No formal response to comments will be provided. A review of constructability, bidability, claims prevention, operability, and environmental control issues will be addressed in the $60 \%$ review. Following review and comment, the major elements of the design 
will be considered "fixed," and the remaining details of the project will be developed in the final design phase on that basis.

\subsection{PREFINAL/FINAL DESIGN (TITLE II, 90\%, 100\%, AND CFC)}

The prefinal (Title II, 90\%) design by the RD contractor will be technically complete. The prefinal design will undergo final internal technical reviews for constructability and operability of the system to ensure that the design successfully integrates the various components and equipment into a working system. An environmental review will also be performed to ensure compliance with ARARs. Experienced engineering and regulatory personnel will be used for the performance of these reviews.

The $90 \%$ design package will be issued to $\mathrm{DOE}$, the construction management contractor, and the facility management contractor as the "D0" design package for review and comment. Additionally, the $90 \%$ design package will also be submitted to EPA and TDEC for review and comment. An on-board review of the $90 \%$ package will be conducted. Upon resolution of comments, the final design (100\%) for Title II remedial activities will be issued to EPA and TDEC for approval as the "D1" submittal. Agency comments will then be incorporated to prepare CFC design documents. The final design drawings and specifications incorporating agency comments will be signed, sealed, and dated by professional engineers who are registered in the state of Tennessee, then issued as CFC.

\section{REMEDIAL DESIGN SCHEDULE}

Figure 5.1 presents the detailed schedule for performing the RD activities for the remediation of this project. This schedule is based on detail network logic. All durations are expressed in working days ( 5 days per week). The basis and assumptions considered for the preparation of the RD schedule are presented below.

- The ROD was signed August 18, 1995.

- FWENC will receive the statement of work and design basis from Energy Systems before the start of the RD.

- The RD will begin November 1, 1995.

- An on-board review of the intermediate RD package (60\%) will be held on February 6, 1996. Advance review copies of the $60 \%$ design will be distributed January 30, 1996.

- The prefinal $\mathrm{RD}$ package ( $90 \% /{ }^{\prime c} \mathrm{D} 0$ ") will be issued March 21,1996 , for review prior to the 90\% on-board review on April 23, 1996.

- The final RD package (100\%/“D1") will be issued May 21, 1996.

- $\quad$ The RD report will be approved by June $21,1996$.

- Assuming regulatory agency approval based on the "D1" design no later than June 21, 1996, the CFC package will be issued July 9, 1996.

- Area 2 of Industrial Landfill V, which is currently being bid for construction, will be available by the beginning of the soil excavation phase.

- To meet the established 15-month duration from the approval of the ROD to the start of construction, initiation of access agreements will constitute the start of RA activities. 


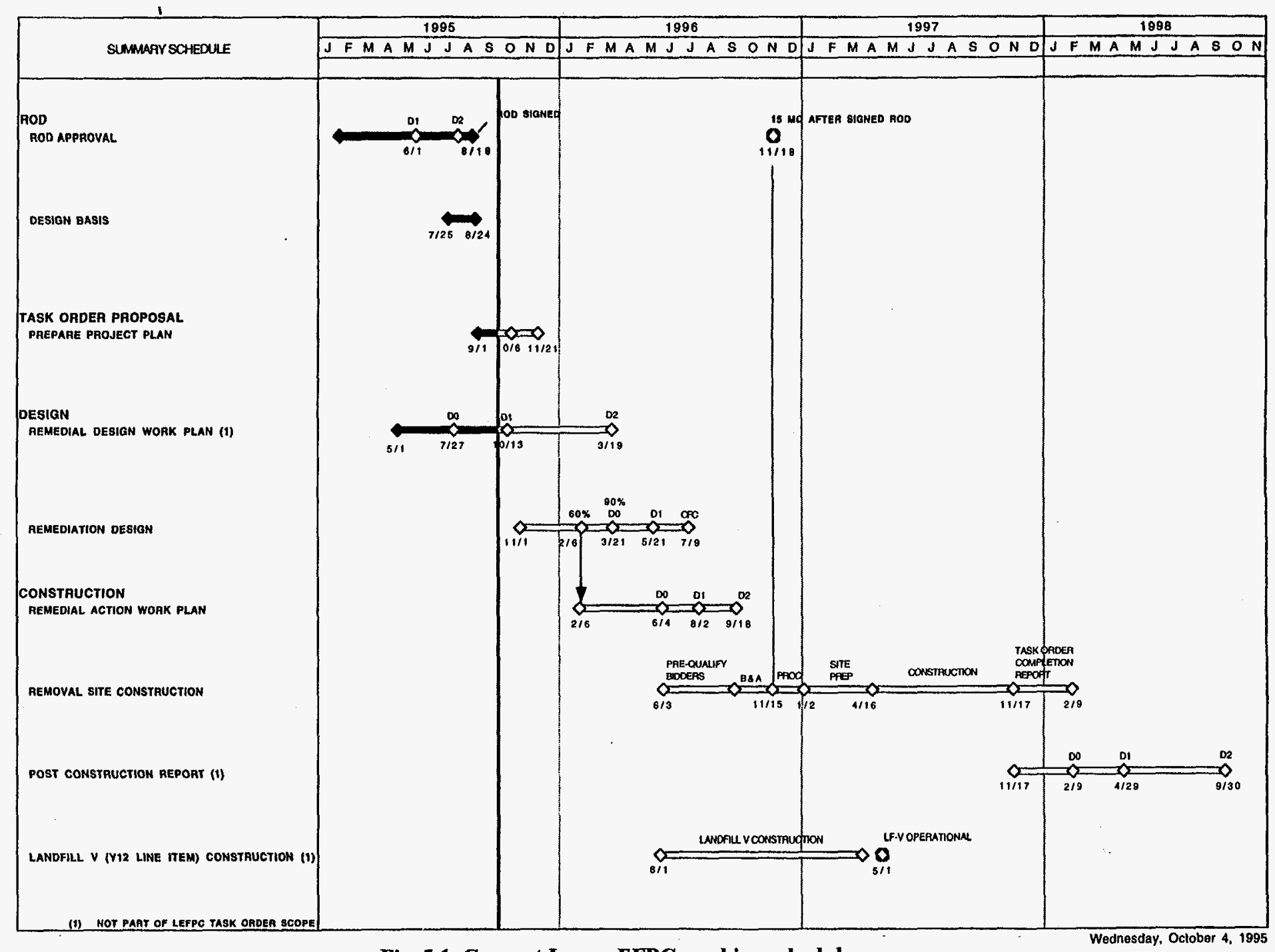

Fig. 5.1. Current Lower EFPC working schedule. 


\section{REFERENCES}

Ebasco 1992. Environmental Restoration and Waste Management Program Quality Assurance Plan.

DOE (U.S. Department of Energy) 1992. Federal Facility Agreement for the Oak Ridge Reservation, DOE/OR-1014, U.S. Environmental Protection Agency Region IV, Atlanta, Ga., U.S. Department of Energy, Oak Ridge Operations, Oak Ridge, Tenn., and Tennessee Department of Environment and Conservation, Nashville, Tenn. January 1.

DOE 1994a. East Fork Poplar Creek-Sewer Line Beltway Remedial Investigation Report, DOE/OR/02-1119\&D2. Prepared for DOE by Science Applications International Corporation, Oak Ridge, Tenn., under Contract DE-AC05-910R21950.

DOE 1994b. Feasibility Study for the Lower East Fork Poplar Creek-Sewer Line Beltway, DOE/OR/02-1185\&D2, Volumes 1 and 2. Prepared for DOE by Science Applications International Corporation, Oak Ridge, Tenn., under Contract DE-AC05-91OR21950.

DOE 1995a. Proposed Plan, East Fork Poplar Creek-Sewer Line Beltway, Oak Ridge, Tennessee, DOE/OR/02-1209\&D3, Oak Ridge Natl. Lab.

DOE 1995b. Record of Decision for Lower East Fork Poplar Creek, Oak Ridge, Tennessee, DOE/OR/02-1370\&D2, Oak Ridge Natl. Lab. 
APPENDIX A

List of ARARs 

Applicable or Relevant and Appropriate Requirements

\begin{tabular}{l} 
Actions \\
\hline Chemical-specific \\
Presence of contaminants in deep \\
groundwater \\
Location-specific \\
Presence of wellands as defined in \\
Executive Order $11990 \$ 7(\mathrm{c})$ \\
\\
Presence of jurisdictional wetlands as \\
defined in 40 CFR $230.3(1)$ and 33
\end{tabular}

CrR 328.3(b)

Must comply with SDWA MCLs and SMCLs for groundwater below 20 ft from the soil surface - relevant and appropriatc

Requirements

Citation

40 CFR 141

TDEC $1200-5 \cdot 12$

Whenever possible, actions involving federal activities and programs affecting land use must avoid or minimize adverse impacts on wetlands and act to preserve and enhance their natural and beneficial values. New Construction in wellands areas should be particularly avoided unless there are no practicable alternatives. Wetlands protection considerations shall be incorporated into planning, regulating, and decision-making processes - applicable

Action to avoid degradation or destruction of wetlands must be taken to the extent possible. Discharges for which there is a practicable alterative with less adverse impacts or those which would cause or contribute to significant degradation are prohibited applicable

Executive Order 11990 10 ClR 1022

Must comply with the general and specific terms and conditions of NWP 13 (Bank Stabilization), NWP 14 (Road Crossings), NWP 18 (minor Discharges), NWP 38 (Cleanup of Hazardous and Toxic Waste), or others if authorized by COE for minor adverse environmental effects - applicable

Must comply with the substantive requirements of the individual permitting process for alterations to "waters of the U.S." which cause more than minimal individual or cumulative adverse environmental effects - applicable

Within area encompassing or affecting waters of the state of

Tennessee as defined in TCA 69-3.

103(32)

Discharge of "substances" into the waters of the state which "will result or will likely result in harm, potential harm or detriment to the health of animals, birds, fish, or aquatic life" is prohibiled - applicablc

Must comply with the substantive requirements of the aquatic resource alteration individual or general permits for activities such as noncommercial sand and gravel dredging, bank stabilization, minor road crossings, wetlands disturbance - applicable

Clean Water Act $\$ 404$

40 CFR 230

33 CFR 323

33 CFR 330, Appendix A 
Applicable or Relevant and Appropriate Requirements (continued)

\begin{tabular}{|c|c|}
\hline Actions & Requirements \\
\hline $\begin{array}{l}\text { Within "lowland and relatively flat } \\
\text { areas adjoining inland and coastal } \\
\text { waters and other floodprone areas...." } \\
\text { [lixecutive Order } 11988 \S(\mathrm{c}) \text { ] }\end{array}$ & $\begin{array}{l}\text { Action shall be taken to reduce the risk of flood loss, minimize the impact of floods on } \\
\text { human safety, leealth and welfarc, and restore and preserve the natural and beneficial } \\
\text { values of floodplains during federal activities involving acquisition, management, and } \\
\text { disposition of lands and facilitics or conducting any federal activities and progrants } \\
\text { affecting land use. The potential effects of actions in floodplaius shall be evaluated and } \\
\text { consideration of flood hazards and floodplain management ensured. If action is taken in } \\
\text { floodplains, alternatives that avoid adverse effects and incompatible development and } \\
\text { minimize potential harms shall be considered - applicable }\end{array}$ \\
\hline
\end{tabular}

Presence of federally owned.

administef Custural resources included in or eligible for inclusion in the National Register of

or historic resources - or - the

likelihood of undiscovered resources

Historic Places (36 CFR 60) or National Historic Landmark Program (36 CFR 65) must be identified - applicable

Action(s) that will affect such resources must be identified and alternatives to the action(s) examined and considered - applicable

\section{Citation}

\section{Execulive Order 11988}

10 CFR 1022

When alteration or destruction of a resource is unavoidable, steps must be taken to minimize or mitigate the impacts - applicable

When alteration or destruction of a resource is unavoidable, steps must be taken to preserve records and data of the resouree - TBC

Consultation with SHPO should be conducted if cultural resources are inadvertently discovered during remediation activities - TBC

Consultation should be initiated with the SHPO and Advisory Council on Historic Preservation before the iniliation of any groundbreaking activities to determine the need for any additional archaeological or historic survey work and the need for an MOA regarding protection of archaeological resources - TBC

Presence of archaeological resources on public land

Presence of archaeologic or historic resources
Steps must be taken to protect archaeological resources and sites for any action involving alteration of terrain which might cause irreparable loss or destruction of significant scientific, prehistoric, historic, or archaeologic data - applicable

A survey of affected areas for resources and data should be conducted and steps taken to recover, protect, and preserve data therefrom or request that DOI do so; the Secretary of Interior must be advised of the presence of the data - TBC
National Historic Preservation Acl (16 USC 470a-w

Executive Order 11593 36 CFR 800

16 USC 4708 6 ClR 800

Archaeological Resources Recovery Act of 1979 (16 USC 470aa-11);

43 CFR

Archaeological and Historic Preservation Act (16 USC 469a-c) 
Applicable or Relevant and Appropriate Requirements (continued)

\begin{tabular}{|c|c|c|}
\hline Actions & Requirements & Citation \\
\hline \multicolumn{3}{|l|}{ Action-specific } \\
\hline \multirow[t]{4}{*}{$\begin{array}{l}\text { Construction/excavation/transport of } \\
\text { soils }\end{array}$} & $\begin{array}{l}\text { Must take reasonable precautions to prevent particulate matter from becoming airborne } \\
\text { during handling or transporting of any matcrials - applicable }\end{array}$ & TDEC 1200-3-8-.01 \\
\hline & $\begin{array}{l}\text { Mercury releases through airborne particulates or burning are subject to State air toxic } \\
\text { program requirements to mect PEL/REL at the AOC boundary, but permits will not be } \\
\text { required - applicable }\end{array}$ & $\begin{array}{l}\text { TDEC } 120-3-3 \\
\text { TDEC } 1200-3-4 \\
\text { TDEC } 1200-3-11.04\end{array}$ \\
\hline & $\begin{array}{l}\text { Excavation and construction adjacent to the creek may be subject to the substantive } \\
\text { requirements under an Aquatic Resources Alternation Permit, but the permit is not } \\
\text { required - applicable }\end{array}$ & TDEC 1200-4-3 \\
\hline & $\begin{array}{l}\text { U.S. DOT requirements for shipment of hazardous or radioactive waste may be } \\
\text { applicable to soil transportation from } A O C \text { to } Y-12 \text { - relevant and appropriate }\end{array}$ & 49 CFR 173 \\
\hline \multirow[t]{4}{*}{ Surface water control } & $\begin{array}{l}\text { Comply with the substantive requirements of the stormwater permitting process for } \\
\text { discharges associated with construction activity, including clearing, grading, and } \\
\text { excavation that result in a disturbance of } 5 \text { acres or more lotal land and implement } \\
\text { good site planning and BMPs to control stormwater - applicable; relevant and } \\
\text { appropriate for less than } 5 \text { acres }\end{array}$ & TDEC $1200-4-10-.05$ \\
\hline & $\begin{array}{l}\text { Implement a BMP to address each component of a system capable of causing a release } \\
\text { of significant amounts of hazardous or toxic pollutants to waters of the U.S. - } \\
\text { applicable }\end{array}$ & 40 CFR 125.104 \\
\hline & $\begin{array}{l}\text { All cost-effective and reasonable BMPs for nonpoint source control shall be } \\
\text { implemented - applicable }\end{array}$ & \\
\hline & $\begin{array}{l}\text { Groundwater infiltration to excavation which is collected for discharge to EFPC must } \\
\text { meet Ground Water Quality Standards. prior to discharge it must be treated to meet } \\
\text { Ambient Water Quality Criteria or POTW release limits - applicable }\end{array}$ & TDEC 1200-4-6-.05 \\
\hline Waste pile & $\begin{array}{l}\text { Pile used for the storage of particulate RCRA hazardous waste must be managed to } \\
\text { control wind erosion and surface water runoff - relevant and appropriate to soil } \\
\text { containing RCRA constituents }\end{array}$ & $\begin{array}{l}40 \text { CFR } 264.250(c) \\
\text { TDEC } 1200-1-11-.06(-12)(b)\end{array}$ \\
\hline
\end{tabular}


Applicable or Relevant and Appropriate Requirements (continued)

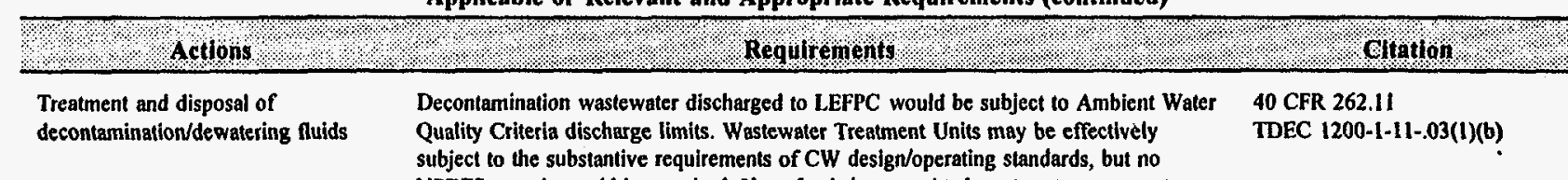
subject to the substantive requirements of $\mathrm{CW}$ design/operating standards, but no NPDES permit would be required. Use of existing permitted wastewater treatment
plants at $Y-12$ would require modification of those permits - applicable

Direct discharge to surface water Must meet water quality criteria for the designated use - relevant and appropriate

TDEC 1200-4-3; bady

Must meet NPDES permit limitations for any discharge via permitted outfalls applicable

Discharge to publicly owned

treatment works (POTW)

Pollutants that pass through the POTW without treatment, interfere with POTW

operation, or contaminate POTW sludge are prohibited. A local POTW permit would be required - applicable

Discharge must comply with local POTW pretreatment standards - applicable

Storage of Hazardous Waste

Storage of hazardous secondary wastes or residues in containers for greater than 90 days would be subject to the substantive facility design and operating requirements under 40 CFR 264 Subpart I, but no RCRA permit would be required. Container storage at satellite accumulation areas or Less-than-90 day areas also may be subject to these requirements as specified at 40 CFR 262 Subpart C - relevant and appropriate

Storage of hazardous secondary wastes or hazardous wastewater in tanks for greater than 90 days is subject to the substantive facility design and operating requirements under 40 CFR 264 Subpart J, but no RCRA permit would be required. Tank storage at satellite accumulation areas or Less-than-90 day areas also may be subject to these requirements as specified at 40 CFR 262 Subpart C - relevant and appropriate

Disposal of solid waste

A person who generates solid waste must determine whether that waste is hazardous using various methods, including TCLP or applicalion of knowledge of the hazardous characteristics of the waste based on information regarding the materials or processes used - applicable

Sanitary wastewater

Discharges to waters of the state must be covered by an NPDES permit. Subcontractors must ensure that all sanitary wastewaters are treated and discharged appropriately applicable 
Applicable or Relevant and Appropriate Requirements (continued)

\begin{tabular}{|c|c|c|}
\hline (1. & Bequilroments & Cirition \\
\hline Fugitive Air Emissions & $\begin{array}{l}\text { Must take reasonable precaution to control fugitive dust. Fugitive dust must not be } \\
\text { emitted as visible emissions beyond property boundary lines for more than } 5 \mathrm{~min} / \mathrm{hr} \text { or } \\
20 \mathrm{~min} / \mathrm{day} \text { - applicable }\end{array}$ & TDEC 1200-3-8-.01 \\
\hline Construction Wastes & $\begin{array}{l}\text { Must meet processing requirements for construction/demoltion wastes and landfills - } \\
\text { applicable }\end{array}$ & TDEC $1200-1-7$ \\
\hline
\end{tabular}

Although administrative and procedural requirements are not ARARs for onsite CERCLA activities, adherence to these steps is strongly recommended by EPA because of the effectiveness of these procedures in identifying and protecting sensitive resources.

\author{
ARARs = applicable or relevant and approprlate requirements \\ BMPs = best management practices \\ CFR $=$ Code of Federal Regulations \\ $\mathrm{COE}=$ U.S. Army Corps of Engineers \\ DOI $=$ U.S. Department of the Interior \\ EPA $=$ U.S. Environmental Protection Agency \\ $\mathrm{ft}=$ foot \\ LDRs $\approx$ land disposal restrictions \\ $\mathrm{MCL}=$ maximum contaminant leve \\ MOA = memorandum of agreemen \\ NPDES $=$ National Pollutant Discharge Elimination System
}

\author{
POTW = publicly owned treatment works \\ RCRA = Resource Conservation and Recovery Act \\ SDWA $\approx$ Safe Drinking Water Act \\ SHW $=$ Safe Drinking Water Act
SHPO Historical Preservation Officer \\ SMCL = secondary maximum containment level \\ TCA $=$ Tennessee Code Annotaled \\ TCA $=$ Tennessee Code Annotaled
TCLP $=$ Toxicity Characteristic leaching Procedure \\ TCLP $=$ Toxicity Characteristic leaching Procedure
TDEC $\approx$ Tennessee Department of Environment and Conservation \\ USC $=$ United States Code
}


DOE/OR/01-1395\&D1

\section{DISTRIBUTION}

1. L. V. Asplund

2. M. O. Barnett

3. K. K. Bowdle

4. R. B. Cook

5. M. F. P. DeLozier

6. D. M. Dutton

7. R. Hinzman

8. L. M. Houlberg

9-10. A. K. Lee/DOE-OSTI (2)

11-13. D. M. Matteo (3)

14. D. W. McCune

15. L. W. McMahon

16-20. J. Q. Miller (5)

21. T. W. Morris
22. H. C. Newsome

23. P. L. Osborne

24-25. P. T. Owen (2)

26. S. E. Pate

27. B. Reed

28. M. L. Scudder

29. J. K. Siberell

30. J. E. Stone

31. W.P. Teichert

32. R. W. Weigel

33. S. A. White

34. P. S. Wood

35. W. O. Wood

36. L. O. Wyatt

37. D. E. Zimmerman

38. Central Research Library

39-41. ER Central Doc. Mgmt. Center (3)

42. Y-12 Central Files

43. R. L. Nace, Branch Chief, Nonenrichment Facilities, Oak Ridge Program Division, Office of Eastern Area Programs, Office of Environmental Restoration, EM-423, Trevion 2, U.S. Department of Energy, Washington, DC 20585

44. R. C. Sleeman, Director, Environmental Restoration Division, DOE Oak Ridge Operations Office, P.O. Box 2001, Oak Ridge, TN 37831-8541

45-46. H. M. Thron, Chief, Enrichment Facilities, Oak Ridge Program Division, Office of Eastern Area Programs, Office of Environmental Restoration, EM-423, Trevion 2, U.S. Department of Energy, Washington, DC 20585 (2)

47. S. L. Lankford, DOE Oak Ridge Operations Office, P.O. Box 2001, Oak Ridge, TN 37831-8541

48-57. D. G. Page, DOE Oak Ridge Operations Office, P.O. Box 2001, Oak Ridge, TN 37831-8541(10)

58. J. L. Howard, DOE Oak Ridge Operations Office, P.O. Box 2001, Oak Ridge, TN 37831-8541

59. R. M. Meccia, Foster Wheeler Environmental Corporation, 11 Union Valley Rd., Oak Ridge, TN 37830

60. K. Olson, Foster Wheeler Environmental Corporation, 11 Union Valley Rd., Oak Ridge, TN 37830

61. J. A. Lea, Jacobs Engineering Group, 125 Broadway Avenue, Oak Ridge, TN 37830

62. W. P. Teichert, Science Applications International Corporation, P.O. Box 2502, Oak Ridge, TN 37831

63. T. Myrick, Science Applications International Corportation, P.O. Box 2502, Oak Ridge, TN 37831

64. J. N. DuMont, Camber Corp., 671-B West Emory Valley Road, Oak Ridge, TN 37830 